\title{
MOURNING THE TROUBLES: ANNA BURNS'S MILKMAN AS A GENDERED RESPONSE TO THE BELFAST AGREEMENT
}

\author{
Marcela Santos Brigida ${ }^{1 \times}$
}

Davi Pinho ${ }^{1^{* *}}$

${ }^{1}$ Universidade do Estado do Rio de Janeiro, Rio de Janeiro, RJ, Brasil

\begin{abstract}
The past two decades have produced extensive criticism of the Good Friday/Belfast Agreement's (1999) progressivist logic in its proposal of a "fresh start" as the best way to honour the victims of the armed conflict that took place during the Troubles (1968-1998). In this paper, we argue that, by refusing to forget and to move on without exposing its grief, Anna Burns's novel Milkman (2018) mourns the Troubles in the public arena, undoing the Agreement. With special interest in Burns's narrator and protagonist who evades the reality of violence by "reading-while-walking", we read Milkman as a gendered response to this enforced forgetfulness. If walking the city frames this young woman's trauma within the collective trauma of the Troubles, it also offers the nomadic possibility of refusing the sectarian identities available to her.

Keywords: Anna Burns; The Troubles; Good Friday Agreement; Trauma; Nomadic subjectivities
\end{abstract}

\footnotetext{
"MA in Literary Studies (UERJ), is currently a PhD student in English Literature at Rio de Janeiro State University (UERJ/CNPq), where she holds the position of general editor of Palimpsesto, a student-run journal for postgraduate research in Language and Literature. Since 2019, she has also acted as a content curator for the extensionist project Literatura Inglesa Brasil. E-mail: marcelascastelli@gmail.com. ORCID: https://orcid. org/0000-0002-0951-1603.

${ }^{* *} \mathrm{PhD}$ in Comparative Literature (UERJ/Birkbeck), is professor of English Literature at Rio de Janeiro State University (UERJ). His most recent publications include a special issue of MATRAGA co-edited with Jane Goldman, "Modernist Prose in Contemporaneity" (2020), the collection Conversas com Virginia Woolf (Ape'Ku, 2020), co-edited with Maria Oliveira and Nícea Nogueira, and a book chapter in The Edinburgh Companion to Virginia Woolf and Contemporary Global Literature (Edinburgh UP, 2021). E-mail: davi.pinho@uerj.br. ORCID: https://orcid.org/0000-0003-3438-1895.
} 
In Precarious Life: The Powers of Mourning and Violence (2004), Judith Butler writes that "one mourns when one accepts that by the loss one undergoes one will be changed, possibly for ever" (21). In her effort to ponder upon what makes for a grievable life in contemporary democracies, Butler emphasizes the political dimension of mourning, as it "brings to the fore the relational ties that have implications for theorizing fundamental dependency and ethical responsibility" (Butler 22). It is only by acknowledging trauma and by mourning the lives of others in the public arena that the precariousness of life itself - the fact that we are all subjected to political, environmental, and epidemiological tragedies, even if precarity (much like wealth) is unequally distributed - might serve as a different form of social tie, one that favours interconnectedness and interdependence rather than separation. Though Northern Ireland comes into Butler's argument only as precedent for the extra-legal practice of indefinite detentions without trial (Butler 71), her point that disavowed mourning brings about a dangerous form of national melancholia and paralysis is indeed relevant to Irish studies.

In "Recovery and Forgetting: Haunting Remains in Northern Irish Culture" (2016), for instance, Shane Alcobia-Murphy cites and reaffirms Graham Dawson's argument that "the attempt to overcome the 'legacy of the past' in Northern Ireland, by consigning it to oblivion, is problematic" (Alcobia-Murphy 199), as "it leaves intact deep sources of grief, grievance and antagonism that are rooted in the recent history of the Troubles" (Dawson 2007, 77). Alcobia-Murphy further asserts that a "determination to archive the past and foster shared amnesia is not closure for the victims, but rather the accentuation of their trauma" (199). To develop his point, the critic analyses what he calls pieces of "cultural resistance to such politically prescribed forgetting" (Alcobia-Murphy 199). ${ }^{1}$

By focusing on "the portrayal of victims, and the spectral return of those who have been 'disappeared"' (Alcobia-Murphy 199) as well as reaffirming the enduring presence of the Troubles and its ramifications through those works, Alcobia-Murphy engages with a school within Northern Irish Studies that problematises the language and the logic behind the greatest landmark of the settlement of the Peace Process in Northern Ireland, the Good Friday or Belfast Agreement (BFA). Several scholars and critics (Kelly 2005, 545; McGrattan 2012, 172) have pointed out the absurdity of some of the Agreement's visual and verbal language, highlighting that its enforcement of the construct of a "fresh start" is damaging to those who lived through the conflict. Alcobia-Murphy, therefore, analyses artistic manifestations that rise against the notion of a clean break between pre- and post-Agreement Northern Ireland.

Aligning Alcobia-Murphy's methodology to Butler's political theory as a point of departure, we will look at the ways through which Northern Irish novelist Anna Burns has established an exercise against prescribed forgetfulness. This paper will reveal that, by actively engaging with the wounds of the past, such an exercise makes lost lives and lost communities grievable in Burns's fictional works. Though we draw parallels with her novel No Bones (2001) and with some of her interviews, we will focus on Burns's latest novel, Booker Award-winning 
Milkman (2018). We will argue that Burns's narrative strategies, such as not naming most of the characters, the repetitive and often fragmented language of her narrator, as well as elements and tropes of her plot, such as the protagonist's habit of "reading-while-walking", produce a form of storytelling that resists the Agreement's tenets for how Northern Irish communities should heal. Hence, we identify Burns as part of a group of novelists who have produced fiction interrogating the Troubles and the conflict's legacy since the Peace Process was officially sealed.

\section{Anna Burns's “Troubles” Fiction: The Belatedness of Trauma}

Anna Burns's Milkman brings, in its first sentence, an announcement of the denouement of that which could be one of the plot's biggest points of tension. It lets the reader know from the outset that the novel's main antagonist - Milkman himself - dies. While many critics have praised the cleverness of the novel's opening sentence (Cf. Kilroy 2018; Charles 2018), most have not highlighted what it tells us about the voice of the narrator who unravels the story. "The day Somebody McSomebody put a gun to my breast and called me a cat and threatened to shoot me was the same day the milkman died" (Burns, Milkman 1), Burns's narrator begins.

While the sentences that follow contextualise the relationship between the referred-to milkman and the narrator and help establish to the reader the fact that she was stalked and relentlessly pursued by him², a paramilitary officer twentythree years her senior, the first sentence encapsulates the gender dynamics of the novel and lets us know one of the many identities taken on by the narrator. At this point, we already know she was a victim of violence. The storytelling exercise which is employed as a narrative strategy is quite informative. Together with the announcement of Milkman's death, the fact that this is a first-person narrative lets us know the protagonist survives all the events contained in the plot. A few pages into Chapter 1, we learn she only came to think about the harassment she suffered "twenty years later" (Burns, Milkman 6), so, informed by the Agatha Christie's novels Burns devoured as a young reader, she flirts with the conventions of the thriller but ultimately deflects from them while writing her "Troubles novels"3. In Milkman, that element is deflated of its mystery since the beginning and the work is able to walk into a different, more philosophically inclined, dynamic.

Burns's narrator never names the city, the district or even the time the events in Milkman play out, a narrative strategy quite different from the one Burns adopted in her debut novel, No Bones (2001), which also deals with the Troubles. Although there is a clearly sectarian conflict playing itself out in Milkman, the narrator never calls it by its given name. Nevertheless, Belfast, Ardoyne, and the Troubles haunt the narrative not only from the reader's inferred previous knowledge about the author, but also due to the configuration of the conflict, the city's geography, and references to "the country over the water" - England - and "the country over the border" - the Republic of Ireland. Ultimately, however, the 
novel firmly commits itself, from the start, with some of the characteristics of a witness testimony, for the narrator is mourning an unelaborated (thus unnamed) collective trauma, which she tells through a very concrete traumatic experience, stated in the very opening line of her narrative. The anonymity, the repetitions and markers of this trauma add to that possible reading. This exercise furthers the interpretation of Milkman as a gendered artistic reaction against the ineffectual language of the Belfast Agreement - a literary exercise that establishes grief and mourning as a political task of elaboration of the past.

Anna Burns's fiction lends itself to being aligned with other exponents of post-Agreement literature in the sense that its material is informed by what Stefanie Lehner (2020) has called "the unfinished business of the past" (Lehner, Crossings 140). To the critic, the past which the Agreement signatories hoped would be left behind "haunts the Northern Irish Peace Process, which is reflected and refracted in post-Agreement literature" (Lehner, Crossings 140). In No Bones, published just two years after the signing of the Agreement, Burns had already worked the haunting nature of trauma into her fiction. In one of the many scenes that play out the absurdity of domestic life during the conflict, the narrator tells us of children characters who, growing up during the Troubles, "were doomed, by a legacy, by Ireland, by England, by prehistory, by everything that had gone before them, always and forever to be one, four and six years old" (Burns, No Bones 226).

Having grown up during the Troubles herself, Burns spoke in an interview of the expectations some garnered that she would "move on" from writing about Ireland, a demand to "let go" not dissimilar to the one posed in the Belfast Agreement. The novelist stated, "I think: 'How do I move on?' The Troubles is such an enormous, immense occurrence in my life, and in other people's lives, that it demands to be written about. Why should I apologise for it? It is a very rich, complex society in which to place a fiction" (Allardice, 2018). Here, Burns voices her hunger as a writer to flesh out the variety of fictional imaginings she can draw from the reality of the Troubles. However, she also sheds light over an aspect of the experience of those who lived through trauma, that is, the belatedness of a haunting event.

That the trauma left by the Troubles has a reach that overrides the interdictions imposed by the Agreement is a point often made by critics of that document. Cathy Caruth (1995) argues that "the central Freudian insight into trauma" (8) is that "the impact of the traumatic event lies precisely in its belatedness, in its refusal to be simply located, in its insistent appearance outside the boundaries of any single place or time" (8-9). This is something Burns develops in Milkman. The narrator, while describing her horror as Milkman's harassment becomes more frequent and she is unable to simply refuse him due to the power disparity between the two, tells the reader:

Also, why was he acting as if he knew me, as if we knew each other, when we did not know each other? Why was he presuming I didn't mind him beside me when I did mind him beside me? Why could I just not stop this running and tell this man to leave me alone? Apart from 'where did 
he come from?' I didn't have those other thoughts until later, and I don't mean an hour later. I mean twenty years later. (Burns, Milkman 10)

The impact of the traumatic event lingers, and it takes the victim many years to be able to even begin to question and elaborate on it. This is an illustration of a point argued by critics of the Agreement's progressivist logic; that by enforcing forgetfulness, the text fails to recognise survivors as victims. The claim that those "who have died or been injured, and their families" can best be honoured "through a fresh start" (Agreement) is problematic not only in the sense that remembrance is a part of the process of making sense of traumatic experiences, but also that the entire community was affected by it. In fact, if we return to Burns's question of "How do I move on?", we realise that this re-enactment and reworking of the Troubles - something Milkman's main character and narrator does by telling her own story in a labyrinthic fashion - is a question inherent to trauma. In Trauma: Explorations in Memory, Cathy Caruth posits that "the attempt to understand trauma brings one repeatedly to this peculiar paradox: that in trauma the greatest confrontation with reality may also occur as an absolute numbing to it, that immediacy, paradoxically enough, may take the form of belatedness" (6-7). Furthermore, drawing on a massive event of shared traumatic experience, Caruth cites Dori Laub's statement that "the Holocaust involved a 'collapse of witnessing"' (Caruth 6-7).

In that sense, Milkman can be read as an attempt at recollection in a moment in which a double interdiction hovers above the narrative. Firstly, there is the difficulty to bear witness to experiences that took place in a state of exception where the narrator felt completely disenfranchised. On a second level, considering she lets the reader know she is narrating events that transpired more than twenty years before, one can infer that she is reliving those experiences under the rule of the Agreement's instruction to start fresh and, as Burns puts it, "move on". Thinking with Butler, we could say that Burns moves backwards towards the future, for it is the traumatic experience of the Troubles that makes "grief itself into a resource for politics" (Butler 30) - not as inaction, but rather as an exposure of everything that was made ungrievable by the Agreement. Between Butler and Burns, one finds that mourning might be a form of non-violent and yet radically transformative political resource. In Butler's words, "it is not that mourning is the goal of politics, but that without the capacity to mourn, we lose that keener sense of life we need in order to oppose violence" (Butler xviii).

Critics have problematised the Peace Process and the Belfast Agreement as a move to reconfigure Northern Irish society and the country's public spaces into a shape compliant to the logic (and processes of disavowed mourning) of Western Capitalism and globalisation. In "Geopolitical Eclipse: Culture and the Peace Process in Northern Ireland” (2005), Aaron Kelly denounces that while "the Peace Process supposedly offers a new, multicultural discourse of equality and reconciliation, a new language and form if you like for Northern Irish society" (Kelly 547), the reality is that the document works to establish "the more 
novel realignment of that society with the economic and political realities of globalisation" (Kelly 547). Kelly furthers his criticism by asserting that while in the surface the Agreement advocates for "new ethical dispensation" (Kelly 547), the process is propelled by an economic reconciliation that leads the country to adhere to "dynamics of a world system and the postmodern, an ideology whose only compass is the flow of capital around the globe" (Kelly 547).

This is a point Lehner also argues for, as she highlights that the affirmation of British-Irish relations that informs the Agreement is an equally political and economic question, "intending, at the time, to re-integrate Northern Ireland into the neo-liberal global dispensation by extending the free market principles of the British 'Third Way' westwards and the (at the time still roaring) Celtic Tiger northwards" (Lehner, Crossings 137). As the critic tells us, Northern Irish poetry was quick to interrogate "the progressivist logic of this new economic corridor, which suggested redevelopment and regeneration through multinational investment as the way forward for a society deemed 'backwards"' (Lehner, Crossings 137). Artistic reactions against the underlying progressivist discourses that looked to split Northern Ireland's history into old and new abound, and we would offer that while Milkman has been read as a Troubles novel, it is as much a work that exercises the tensions inherent to the aftermath of the Peace Process. It can be aligned with other works of post-Agreement literature that

remain acutely aware that the 'staked' past can still sting and that the Peace Process may have created a rather different and more narrow corridor than that envisaged by Longley: one that, in its complicity with a ready-made futurity of global consumerism and neoliberal economics, resembles more a one-way street, as insinuated by the strategic street sign for the Agreement's 'Yes' campaign, reading 'Vote Yes. It's the way ahead'. (Lehner, Crossings 138)

As we will argue, Burns wards off the sectarian organisation of the conflict and the many fault lines of the Agreement's progressivist logic by writing her narrator and main character in a framework of nomadic subjectivity. The nomadic impulse of the narrator is exercised and manifested in the novel not only through her refusal to adhere to the categories available to her, but also through her disappearance into literature in the public space, "reading-while-walking", engaging in flânerie and, thus, disarming the Troubles' power over her.

\section{Milkman as a Gendered Response to Sectarianism: Reading-While- Walking as Nomadic Becoming}

Although Milkman's narrator and protagonist is a catholic whose brothers are "renouncers-of-the-state", that is, who are involved with a paramilitary group similar to the IRA, she repeatedly refuses to engage with the conflict in any way. The paramilitary officer who stalks her stands, in a way, as a personification of the reality of the Troubles, from which she recoils. Furthermore, it is because she 
draws away from the violent reality of a "hair-trigger society" where "violence was everybody's main gauge for judging those around them" (Burns, Milkman 2) that the novel's narrator is set apart and not only noticed by Milkman - meaning the man and the structures of surveillance of the community itself -, but also turned into an object of curiosity and reproach. She reads nineteenth-century novels "because I did not like twentieth-century books because I did not like the twentieth-century" (Burns, Milkman 5) while walking. This habit, which she calls "reading-while-walking", adds another layer to Burns's critique of the Belfast Agreement. This space of the other in a community sectioned into two official groups - loyalists and nationalists - was a problem during the Troubles and remained so after the Peace Process.

The Agreement helps establish and normalise the Two Traditions paradigm in Northern Irish society. In "Culture and the Peace Process in Northern Ireland" (2009), Aaron Kelly posits the categories of Irish Nationalism and Unionism as "shared attempts to occlude the full historical and social complexity of this island, which entails a consideration of class conflicts, popular radicalisms, struggles for women's rights, the dialectics of urbanity, and so on" (548). He further argues that this paradigm, ratified by the Agreement, "frustrates the establishment of a properly constituted public space" (548) as it figures society always in relation to those sectarian categories, asserting their prevalence over those who identify with neither. The critic goes on to argue that despite "its seeming inclusivity and pluralism (embedded in the cultural notion of 'Two Traditions'), such a model actually excludes a vast range of sociopolitical agents and concerns" (Kelly 548). $\mathrm{He}$ cites the procedures of the devolved assembly in Northern Ireland as an example: "for any legislation to be passed a majority is required from members who must identify themselves as either Nationalist or Unionist" (Kelly 548). This is something Pete Shirlow (2004) calls the "institutionalised sectarianism" of the Agreement, arguing that

The fact that members of the Northern Ireland Assembly must designate themselves as nationalist, unionist or other and that all decisions taken must have majority support from both the nationalist and unionist blocs means that the capacity of alternative political interpretations is hindered. (Shirlow 196)

What is portrayed in Milkman as the narrator's unwillingness to engage in or to adhere to the language of sectarianism can be read as the search for an existence outside of the categories of political identity offered to Northern Irish citizens before and after the Agreement. While a violent sectarian conflict is no longer a reality for the Northern Irish, a sectarian organisation of society remains the norm. Those who do not adhere to it are identified as "other" and have few possibilities to engage in political debate.

In that framework, Milkman's protagonist's initiative of telling her story through fiction and Burns's writing itself are equally significant as political acts of "others". Burns's countering of a sectarian organisation of daily life takes its fullest 
expression in the narrator's "reading-while-walking". It is in this surprisingly defiant act of flânerie that the character asserts a different, nomadic subjectivity in opposition to the categories available to her. The only thing that binds her to that place in time is that her life too is vulnerable - a patent mark of all lives in the political spectrum of Troubles-Era Northern Ireland, even if this vulnerability was very unequally distributed, as her position as a young woman in that society reveals. Escaping the division through "reading-while-walking", the narrator is classed as "beyond-the-pales" by her community, an expression that appears around eleven times in the novel to qualify those who "flout convention", who are "a law unto themselves" (Burns, Milkman 219). "Reading-while-walking" as an exercise seems to reveal the narrator's resistance to cultural fixation, to sectarian adherence, even if being beyond the pales might at times make her more vulnerable.

Indeed, this act of defiance by the narrator makes Milkman a novel to be read as we ask some of Butler's beyond-the-pales questions: is it not high time we shift the perspective from the least to the most vulnerable and look into the distribution of precarity around the world? Is this not what really fuels violence? Can grief work towards acknowledging the violence suffered by the most vulnerable and redistribute their precarity? After all, our common human precariousness - the fact that we are all killable and, therefore, that our lives are dependent on one another - is revealed in times, places and through lives marked by extreme precarity. This is what Butler shows in her post-9/11 philosophical investigation. If this is also what Burns expresses through the gendered violence that Milkman's narrator suffers in the fictional city one may read as a correlative of the writer's Troubles-era Belfast, it is this narrator's "beyond-the-pales" act of flânerie that paradoxically exposes her multilayered precarity while at the same time works as resistance against it.

The flâneur was first described by Charles Baudelaire in 1863 as a quintessential figure of modernity. As a writer, the flâneur was characterised by Walter Benjamin (2006) as one who stood "on the threshold of the metropolis and of the middle class" (Benjamin 40) and who sought refuge in the crowd. As a flâneur, the writer could observe the goings of the city without being observed, producing a sellable narrative. The ability to mingle in the capitalist city of the nineteenth century was an exclusively male feat, however. Gender roles established by the rise of the bourgeoisie ensured that the crowd would offer a woman not anonymity, but notoriety, which makes the history of flânerie a heavily gendered one. Hence, in fiction and outside of it, the very existence of the flâneuse as a creative woman who seeks "refuge" in the crowd has been questioned (Cf. Wolff 1985, 37; Vicinus 1985, 149).

Nevertheless, Walter Benjamin suggests that flânerie constitutes not only a trait of the writer who goes to the marketplace "ostensibly to look around, but in truth to find a buyer" (Benjamin 66), but also a form of perception, discussing different incarnations of the flâneur. Bearing this in mind, studies such as Deborah Epstein-Nord's Walking the Victorian Streets: Women, Representation, and the City (1995) emphasise that flânerie shapeshifts, accommodates other 
expressions and lends itself to reconfiguration. Indeed, as the flâneur began to appear in fiction written in English, his female counterpart, the flâneuse, was not simply a creative woman who strolled to observe and write, but one who, as the term streetwalker informs us, would have a disreputable social standing, taking the form of the prostitute or of the pickpocket.

Reading in the gaps of Raymond Williams, Epstein-Nord establishes that, while walking alone in the city immediately presented women as "endangered or dangerous" (Epstein-Nord 241), since the rise of the novel we can find women who penetrate the public arena through transgression and produce an urban vision of their own. From Daniel Defoe's Moll Flanders (1722) to Victorian novels such as Charles Dickens's Dombey and Son (1848) and Elizabeth Gaskell's Mary Barton (1848), the disruptiveness of the woman who breaks through interdiction to stroll produces distinct traits for the literary figure identified as flâneuse. Thus, if the flâneur and the flâneuse share a common principle as literary figurations that produce critiques of modernity, their critiques differ precisely because of the social constructions and demands of masculinity and femininity.

While social customs and legislation have made the Western city available for creative women in late modernity, the contemporary flâneuse continues to raise questions of gender and to resist the fixed identities enforced by the capitalistic logic of commodification, as Milkman reveals. The kind of flânerie practised by Burns's contemporary narrator comes as a trope for nomadic subjectivities. In other words, Milkman, as a novel that takes place in a late-twentieth-century State of Exception fractured by sectarian violence and riddled with strict gender constructs, establishes the narrator's subjectivity in a position of alterity in relation to the categories of accepted, fixed identity. This is elaborated by Burns around the character's impulse towards mobility in a community where even moving between districts could lead to reprimands.

If we take the character's habit of reading novels while rambling as Milkman's main question, one that otherises her to the point of her being classed as one of the community's "beyond-the-pales", we see here a resurgence of the disruptiveness of the flâneuse that can be tensioned against not only the experience of the Troubles inside the novel and outside of it, but as Burns's interrogation of the Agreement's progressivist logic, one that is "symptomatic of the strategic containment of history" (Lehner, The Peace Process 2007, 507). If "history is always written from the sedentary point of view and in the name of a unitary State apparatus" (Deleuze and Guattari 2005, 23), in writing Milkman, Burns aligns herself with a counter current of artistic responses to the proposal of a "fresh start".

The image of the narrator, a young woman who occupies a place of alterity in her community primarily because of her ramblings, both reinforces the notion that the flâneuse appears in the novel as a disruptive, transgressive figure and tells us that Burns employs flânerie as a point of access to identity as becoming for a character that evades the binary categories available to her. Milkman upholds Rosi Braidotti's idea that, since we "live in permanent processes of transition, hybridization, and nomadization", the "in-between states and stages defy the 
established modes of theoretical representation, precisely because they are zigzagging, not linear and process oriented, not concept driven" $(2011,217)$. The narrator's defining trait - her reading-while-walking - thus comes as a figuration of a nomadic subjectivity:

Figurations are forms of literal expression of the politics of location that bring into representation that which the dominant system had declared off-limits. They are situated practices that require the awareness of the limitations as well as the specificity of one's locations. A figuration renders our image of thought in terms of a decentered and multilayered vision of the subject as a dynamic and changing entity; as such it can be taken as a dramatization of the processes of becoming. This process assumes that identity takes place in between nature/technology, male/female, black/ white, local/global, present/past-in the spaces that flow and connect such seeming binaries. (Braidotti 217)

To those binaries we can add layers such as unionist/loyalist as well as Pre-/ Post-Agreement Northern Ireland. Furthermore, by establishing a dialogue between the novel and the language of the Belfast Agreement, one can argue that Burns articulates all of those categories to establish in the novel the ineffectuality of the Agreement's interdictions and its very project of a gentrified and global Belfast, fully disengaged from the city that lived through constant bombings, civil unrest and sectarian violence. Instead of complying with this forged and violent peace, Burns writes a novel that mourns her traumatic experience in the Troubles. For, indeed, Milkman never eschews this collective grief, even if it remains unnamed as Burns tackles it from the singular point of view of a woman who bears witness to the multilayered precarity that marked her life as a girl in a collectively precarious city. By bringing Braidotti into dialogue with Butler and Caruth, it becomes clear that an experience such as the Troubles does not lend itself to a project of enforced rupture, of ungrievable erasure. Ultimately, Burns's fiction can be read alongside Cillian McGrattan's assertion that "the desire to move away from what is painted essentially as a bad past towards a future utopia is profoundly anti-democratic" (177).

\section{Bearing Witness}

Asked in an interview what inspired her to write Milkman, Burns identified her own practice of reading-while-walking in Belfast during the Troubles, and the curiosity it elicited in her neighbours as the first element that came to her. Burns mentioned she wished to put order to "a few hundred words of notes" to start writing a short story which she would then send to a magazine. Those notes were

about reading-while-walking which I used to do a lot. People would say to me, including strangers in clubs and shops and bars and cafés, 'You're that girl who reads and walks!' I would continually be startled at having this pointed out, mainly because it seemed an activity not particularly worthy of note. And also, I was surprised to be noticed doing it by so many people. 
I wanted to try to write something around the possible reasons why this was being pointed out to me, rather than about the activity of reading while walking itself. (Moraif)

In the novel, the narrator's relationship with the city is mediated by her avoidance of it. While the eighteen-year-old always prefers to walk places, she does so while immersed into nineteenth-century novels. In that sense, her relationship with public space is as peripheral as she wishes her own position in that society to be. Like the nineteenth-century flâneuse - and here it is interesting to consider how she reads nineteenth-century novels only -, her ramblings make her into a target. The eighteen-year-old's introspection raises the curiosity of the community and rumours are spread about her as soon as the forty-one-year-old paramilitary leader, Milkman, takes up an interest in her. That gossip spreads so quickly, and that it works as a taint to her standing in the community but not to his tells us something both about the position of women in that society as well as about the far-reaching effects of the version of events those in power propagated.

Furthermore, in Milkman, gossip evidences the inaccessibility of any construction of a sense of truthfulness in a society that lived in fear and often communicated through rumours: "As for the rumour of me and the milkman, I dismissed it without considering it. Intense nosiness about everybody had always existed in the area. Gossip washed in, washed out, came, went, moved on to the next target" (Burns, Milkman 5). It can be easily inferred that Milkman himself initiates the rumours to ascertain ownership over the narrator, keeping other men away from her (further along the plot he even threatens to kill her "maybe-boyfriend") and, simultaneously, to keep control over a narrative that corners the narrator into accepting him, as her neighbours and family distance themselves and isolate her.

The first meeting between the narrator and Milkman establishes the dynamics of his pursuit of her. Milkman approaches the narrator from his car as she walks while reading Sir Walter Scott's Ivanhoe (1819). She tells the reader she often walked while reading books and that, while she saw nothing wrong in her habit, reading-while-walking soon "became something else to be added as further proof against me" (Burns, Milkman 3). The passage is very informative of Milkman's approach. He mentions he knew her father and brothers, and she states he looked "smiling and friendly by way of being obliging" (Burns, Milkman 3) while offering her a lift. However, "by age eighteen, 'smiling, friendly and obliging' always had me straight on the alert" (Burns, Milkman 3). There are clearly sexual undertones to his offer, but also an implication that this invitation is not one she could outrightly refuse due to his naming of her male family members: "I did not want to get in the car with this man. I did not know how to say so though, as he wasn't being rude and he knew my family for he'd named the credentials, the male people of my family, and I couldn't be rude because he wasn't being rude" (Burns, Milkman 3). After some hesitation, her response is to reaffirm her status as a walker, and as a reader: "So I hesitated, or froze, which was rude. 'I'm walking,' I said. 'I'm reading, and I held up the book, as if Ivanhoe should explain the walking, the necessity for walking" (Burns, Milkman 3) and 
although he insists that she could read in the car, the man eventually drives away after telling her to "enjoy her book" (Burns, Milkman 4).

While the narrator's reading-while-walking sets her apart in a society where she was not supposed to call attention to herself and exposes her to the scrutiny of her neighbours, it also works on at least two levels to help her deflect from engaging with the categories of identity imposed over her in that particular version of her country. A friend involved with the "renouncers of the state" nationalists - decries reading-while-walking as something that calls attention to the narrator: "It's disturbing. It's deviant. It's optical illusional. Not publicspirited. Not self-preservation. Calls attention to itself and why ... would anyone want to call attention to themselves here?" (Burns, Milkman 200). However, while "not self-preservation", reading-while-walking is what permits the girl to refuse Milkman's lift in that first attempt. The narrator's immersion into her exercise of reading-while-walking, which allows her to experience her city in a manner that is inaccessible to any of her neighbours, is an exercise of creativity in itself. And if, as Rosi Braidotti argues, "creativity is a nomadic process in that it entails the active displacement of dominant formations of identity, memory, and identification" (Braidotti 151), we can say Burns finds an ideal tool to build a character and a plot that evade both the categories the Troubles would force upon young women, but also recognises the far-reaching effects of having to evade them for so long. The girl becomes the narrator of her own story more than two decades later by leaving the position of the reader immersed into a nineteenthcentury novel to occupy that of a storyteller that turns to the century she loathed to question, to elaborate and to share her own traumatic experiences, which are different but intertwined with the traumatic experience of her community.

Burns's strategy of adhering to an aesthetic of namelessness in Milkman adds to the character's and the story's elusiveness. If we read the novel as a woman in charge of telling her own story, her choices of naming and non-naming can also be interpreted as a gendered response to the violent silencing mechanisms of pre- and post-Agreement Northern Ireland. While Milkman's narrator does not name herself, the place where she lives, other characters or even her country, the name of the man who stalks her and who personifies the violence, the misogyny, and the powerlessness she felt is the only one she shares. She does so before the story even begins, as the book is titled after her abuser. However, even this sort of public-shaming is ambiguous as it is only at the end of the novel that it is revealed to the reader that "the milkman" was not a codename or a nickname, but rather the paramilitary officer's surname, Milkman.

After they shot him, and the six unfortunates who'd got in the way of him, it was revealed, along with his age, abode, 'husband to' and 'father of', that Milkman's name really was Milkman. This was shocking. 'Can't be right', cried people. 'Farfetched. Weird. Silly even, to have the name Milkman'.... Alarmists, meanwhile, continued to debate over the provenance of the Milkman name. Was it one of ours? One of theirs? Was it from over the road? Over the water? Over the border? Should it be allowed? Banned? 
Binned? Laughed at? Discounted? What was the consensus? 'An unusual name,' everyone, with nervous caution, after great deliberation, said. ...

[T] he news of this Milkman name unsettled people; it cheated them, frightened them and there seemed no way round a feeling of embarrassment either. When considered a pseudonym, some codename, 'the milkman' had possessed mystique, intrigue, theatrical possibility. Once out of symbolism, however, once into the everyday, the banal, into any old Tom, Dick and Harryness, any respect it had garnered as the cognomen of a high-cadre paramilitary activist was undercut immediately and, just as immediately, fell away. People consulted phonebooks, encyclopaedias, reference books of names to see if anyone, anywhere in the world had been called Milkman. Many were left stranded, uncomprehending, with nothing for it but to grow speculation, both in the media and in the districts, over just who exactly this Milkman person was. (Burns, Milkman 304-305)

On an external level, the passage above reveals how Burns defies an element of the Peace Process that critics have identified as "archive fever", as Lehner explains: "[Colin] Graham notes that part of the Peace Process 'has been to filter out that which does not fit into or attend on the present moment ... Thus, the difficult and the embarrassingly recent past, or the non-conforming present, is archived"' (Lehner, The Peace Process 507). Is it possible that, by naming her abuser - even if only after his death and after remembering the feeling that, finally, her "body was proclaiming, 'Halleluiah! He's dead. Thank fuck halleluiah!'” (Burns, Milkman 302)_, Milkman's mature narrator decides to bear witness to the "difficult and embarrassing recent past, or the non-conforming present"? "[M]aybe I'll calm down now, maybe I'll get better now, maybe this'll be the end of all that 'don't let it be Milkman, oh please don't let it be Milkman"' (Burns, Milkman 302), the woman in charge of telling her own story remembers longing for the chance to heal as a girl. Telling the story, then, bears witness to the traumatic experiences of her youth at the same time that it allows her to mourn and honour her many losses.

We believe that this complex structure of remembering and enunciating one's grief is symptomatic of the sense that the experience of the Troubles remains a part of Northern Irish emotional reality, in spite of the problematic project of enforcing a break between Troubles-Era and Post-Agreement Northern Ireland. While Anna Burns's voice is her own, she takes part in a tradition of Northern Irish women writers who "have used their fiction to comment on the changing nature of their society" (Magennis 2018, 365). Such novels "powerfully explore the legacy of violence and complicate simple narratives of sectarian conflict with a focus on gender, class and embodiment" (Magennis 365). In Milkman, the novelist offers her reader several points of access to a fictional account of life for a young woman during the Troubles, communicating not only the toll the experiences took on her as they happened, but the way they are part of her present and future.

The act of storytelling reaffirms the longevity and the impact of traumatic experiences, exercising through language the ineffectuality of the Belfast Agreement's prescription for a "fresh start". Burns's novel also interrogates the simplification of complex Northern Irish identities to a loyalist/unionist binary. This is achieved by the construction of a character who responds to the harshness 
and the scrutiny of her community by turning to "reading-while-walking". This flânerie, which can be read as a political act of resistance, allows her to occupy an in-between place of alterity as a nomad, one who only belongs because she too has her precariousness exposed. As long as she walks-while-reading, she is not entirely there. As long as she looks at her city as peripheral to the pages of her long, nineteenth-century novels, the reality of bombings and armed violence cannot entirely encompass her.

As many writers have done before her, Anna Burns turns to fiction to try to make sense of Northern Ireland, but her strategy is particularly clever in the sense that literature figures as a way out in the novel itself. Burns firmly sets her main character beyond the reach of the past that haunts her as she looks back at it as its narrator. If in the past, and in much of our present reality, the official version is that of those who are in power, in Burns's fiction the category of the other owns the narrative. After all, to end this discussion where we began, only by operating this radical movement of walking as and towards the other can we "critically evaluate and oppose the conditions under which certain human lives are more vulnerable than others, and thus certain human lives are more grievable than others" (Butler 30).

Notes

1. He turns to three artworks: David Farrell's series of photographs Innocent Landscapes (1999-2000), Willie Doherty's video projection Ghost Story (2007), and Seamus Deane's novel Reading in the Dark (1996).

2. "It had been my fault too, it seemed, this affair with the milkman. But I had not been having an affair with the milkman. I did not like the milkman and had been frightened and confused by his pursuing and attempting an affair with me" (Burns, Milkman 1).

3. Stefanie Lehner tells us that "the thriller was the predominant mode for representing the Troubles, and a notable number of Peace Process fictions have employed elements of the form, which has proven especially able to register the temporal and spatial crossings underpinning the Agreement, while contesting the notion that it could draw 'a line under the past"' (Crossings 142).

\section{References}

Agreement, Good Friday. The Agreement: Agreement Reached in the Multi-party Negotiations, 10 April 1998 (Good Friday or Belfast Agreement), 1998, http://cain. ulst.ac.uk/events/peace/docs/agreement.htm

Alcobia-Murphy, Shane. "Recovery and Forgetting: Haunting Remains in Northern Irish Culture." The Body in Pain in Irish Literature and Culture, edited by Fionnuala Dillane, Naomi McAreavey and Emilie Pine, Palgrave Macmillan, 2016, pp. 199215.

Allardice, Lisa. "Interview: 'It's nice to feel I'm solvent. That's a huge gift': Anna Burns on her life-changing Booker win". The Guardian, 17 Oct. 2018, www.theguardian. com/books/2018/oct/17/anna-burns-booker-prize-winner-life-changinginterview. Accessed 2 June 2020.

Benjamin, Walter. The Writer of Modern Life: Essays on Charles Baudelaire, edited by Michael W. Jennings, Harvard UP, 2006. 
Braidotti, Rosi. Nomadic Theory: The Portable Rosi Braidotti. Columbia UP, 2011.

Burns, Anna. Milkman. Faber and Faber, 2018.

No Bones. 2001. $4^{\text {th }}$ Estate, 2018.

Butler, Judith. Precarious Life: The Powers of Mourning and Violence. Verso, 2004.

Caruth, Cathy (Ed.). Trauma: Explorations in Memory. Johns Hopkins UP, 1995.

Charles, Ron. "Milkman' - one of the most challenging books of the year - is also one of the most rewarding." The Washington Post, 4 Dec. 2018, www.washingtonpost. com/entertainment/books/milkman--one-of-the-most-challenging-books-ofthe-year--is-also-one-of-the-most-rewarding/2018/12/04/c3be904c-f764-11e88c9a-860ce2a8148f_story.html. Accessed 2 June 2020.

Dawson, Graham. Making Peace with the Past? Memories, Trauma and the

Irish Troubles. Manchester UP, 2007.

Deleuze, Gilles; Guattari, Félix. A Thousand Plateaus: Capitalism and Schizophrenia. 1980. U of Minnesota P, 2005.

Epstein-Nord, Deborah. Walking the Victorian Streets: Women, Representation, and the City. Cornell UP, 1995.

Kelly, Aaron. "Geopolitical Eclipse: Culture and the Peace Process in Northern Ireland." Third Text, vol. 19, no. 5, 2005, pp. 545-553.

Kilroy, Claire. "Milkman by Anna Burns review - creepy invention at heart of an original, funny novel." The Guardian, 31 May 2018, www.theguardian.com/ books/2018/may/31/milkman-anna-burns-review-northern-ireland. Accessed 2 June 2020 .

Lehner, Stefanie. "Crossings Northern Irish Literature from Good Friday to Brexit." Irish Literature in Transition: 1980-2020, edited by Eric Falci, Cambridge UP, 2020, pp. 136-151.

"The Peace Process as Arkhe-taintment? Glenn Patterson's That Which Was and Eoin McNamee's The Ultras." Irish Studies Review, vol. 15, no. 4, 2007, pp. 507-520.

Magennis, Caroline. “Fiction from Northern Ireland 1921-2015”. A History of Modern Irish Women's Literature, edited by Heather Ingman and Clíona Ó Gallchoir, Cambridge UP, 2018, pp. 365-382.

McGrattan, Cillian. "Moving On': The Politics of Shared Society in Northern Ireland." Studies in Ethnicity and Nationalism, vol. 12, no.1, 2012, pp. 172-189.

Moraif, Aubrey. "Interview with 2019 NBCC Fiction Winner Anna Burns". The New School Creative Writing, 15 Mar. 2019, newschoolwriting.org/interview-with2019-nbcc-fiction-finalist-anna-burns/. Accessed 2 June 2020.

Shirlow, Pete. "Northern Ireland: A Reminder from the Present." The End of Irish History? Edited by Colin Coulter and Steve Coleman, Manchester UP, 2004, pp. 192-207.

Vicinus, Martha. Independent Women: Work and Community for Single Women, 1850-1920. U of Chicago P, 1985.

Williams, Raymond. The Country and the City. Oxford UP, 1973.

Wolff, Janet. "The Invisible Flâneuse. Women and the Literature of Modernity." Theory, Culture \& Society, vol. 2, no. 3, 1985, pp. 37-46.

Recebido em: 09/06/2020

Aceito em: 27/08/2020 